\title{
Evolution of the earth - moon system
}

\author{
Murthy S Gudipati ${ }^{1,2}$
}

\section{Correspondence:}

pseditorinchief@gmail.com

${ }^{1}$ Jet Propulsion Laboratory,

California Institute of Technology, Pasadena, CA 91109, USA

${ }^{2}$ Institute for Physical Sciences and Technology, University of Maryland, College Park, MD 20742, USA
Due to a glitch in the editorial process, the manuscript by Riofrio "Calculation of lunar orbit anomaly" (Riofrio, L., Planetary Science 2012, 1:1) was accepted for publication before the reviewing process was complete.

Post-publication reviews revealed that the observed Earth-Moon distance increase by $\sim 3.82 \mathrm{~cm} / \mathrm{yr}$ derived using Lunar Laser Ranging (LLR) has already been dealt with in the literature without having to assume any new fundamental physics like a cosmological variation of the speed of light as hypothesized by Riofrio in the above-cited publication.

The following new article "The Past and Present Earth-Moon System: the Speed of Light Stays Steady as Tides Evolve" by James G Williams, Slava G Turyshev, and Dale H Boggs, Planetary Sciences 2014, 3:2, addresses the issue of Earth-Moon distance variations again in a greater detail and confirms that no changes in fundamental physics are necessary to explain the observations.

\section{Dr. Murthy S. Gudipati \\ Editor-in-Chief, Planetary Sciences}

Received: 10 January 2014 Accepted: 14 January 2014

Published online: 04 April 2014

doi:10.1186/s13535-014-0001-6

Cite this article as: Gudipati: Evolution of the earth - moon system. Planetary Science 2014 3:1

\section{Submit your manuscript to a SpringerOpen ${ }^{\odot}$} journal and benefit from:

- Convenient online submission

- Rigorous peer review

- Immediate publication on acceptance

- Open access: articles freely available online

High visibility within the field

Retaining the copyright to your article

Submit your next manuscript at $>$ springeropen.com

(c) 2014 Gudipati; licensee Springer. This is an Open Access article distributed under the terms of the Creative Commons Attribution License (http://creativecommons.org/licenses/by/2.0), which permits unrestricted use, distribution, and reproduction in any medium, provided the original work is properly cited. 